Seimerling also draws our attention to the many ways in which it is necessary to witness the past. A common theme in many of the novels he discusses is characters witnessing the narratives of others; In Lorris Elliott's Other Voices, for instance, Mary Ann Shadd communicates with the ghost of Angelique, playing witness to her story (156-157); in Lawrence Hill's Any Known Blood, the protagonist becomes a witness as he researches his family history (158). Seimerling argues that the readers of these books are likewise called upon to act as witnesses to the stories unfolding within. Witnesses becomes an active rather than a passive phenomenon, wherein the participants have a real and enabling power to bring crucial truths from the past into the present.

Overall, Siemerling's book should be recommended to not just those with an interest in black Canadian writing, but anyone who studies the history of Canada, or the histories of Africans and their descendants in any part of the world. It is also a highly useful tool for educators seeking to provide historical narratives that more fairly represent these crucial aspects of the histories of Canada and the black Atlantic at large.

Maryann Buri

York University

\title{
Wendy Matsumura, The Limits of Okinawa: Japanese Capitalism, Living Labor, and Theorizations of Community (Durham: Duke University Press, 2015). 288pp. Hardback \$94.95.
}

This is by far the best history available in English of Okinawa between 1879, when it was forcibly annexed by Japan, and the depression years of the 1930s. Appropriately focusing on economics, Matsumura persuasively applies current interpretations of Marxist theory to show the political, social and cultural effects of corporate and government efforts to make of Okinawans what Marx called "dead labor" for the sugar and textile industries, and describes how workers and farmers resisted them. The author defines "struggles between living labor-that part of labor associated with the needs and desires of workers and producers - and dead labor-the uncreative and unproductive part of the organic composition of capital" (118). Mainland corporations, often with the support of the national and prefectural governments, sought to force Okinawan growers to supply maximum quantities of sugar, Okinawa's largest cash crop, in an easily processed form for mass-production in factories at inferior wages and working conditions. For their part, the growers fought to retain control over what they produced and the land they farmed, as well as the power to negotiate wages and working conditions.

Matsumura argues against histories of Okinawa based on narratives of dependency and victimization. Instead of assuming, as many authors do, that the government in Tokyo was responsible for imposing harsh policies on Okinawa, she 
focuses on local leaders' support of them. Ota Chofu (1865-1938), an influential journalist who also served as a city mayor and prefectural assemblyman, advocated what Matsumura calls economic nationalism to protect "Okinawa's small producers against mainland capital.” Otherwise, Ota “anticipated Okinawan society...would be gradually expelled from their lands and transformed into tenants or agricultural and industrial wage laborers that provided the necessary labor for capitalist industry" (96). However, far from rejecting capitalism, Ota maintained that it had to serve Okinawans. Matsumura explains: "Economic nationalism was founded on the belief that some forms of exploitation were more benevolent and therefore, more desirable than others - that of Okinawans by other Okinawans...a prerequisite to the ultimate goal of creating an autonomous sphere" (96).

Ota, editor-in-chief, and other intellectuals who wrote for the Ryukyu Shimpo newspaper, insisted that, in order to establish modern industry in the prefecture, "reforms" had to be undertaken of "existing ways of life" in social relations, dress, and other aspects of local culture. He explained: "Though these tactics may seem coercive and unfree, there is nothing more unfree than being employed by someone else" (112). Ota and others feared that, if people did not adjust to changing conditions, "it will be impossible to even retain the appearance of a prefecture" (113). This was no a hypothetical scenario in the first decade of the twentieth century. In 1908 the national government submitted a proposal in both houses of the Diet to transfer control of Okinawa to the Office of the Governor General of Taiwan, which would have effectively reduced the prefecture's status to a colony.

The "reforms" advocated by Ota and the others weighed heavily on women. "Local reformers sought to remove female leaders...from their central position in the spiritual, cultural, and economic lives of village communities at the turn of the century" (101). An article in the 15 August 1900 edition of the Ryukyu Shimpo blamed women for having multiple relations with men that reportedly spread syphilis in farming villages that could destroy entire communities. Matsumura quotes Maria Mies' description of witch hunts in Europe that similarly "denounced female nature as sinful, and sexually uncontrollable, insatiable and ever ready to seduce the virtuous man" (97). In order to impose their vision of a modern textile industry, reformers at the Shimpo sought to wrest it from the hands of female weavers, who produced high-quality cloth admired throughout Japan, insisting that men should do the work, and women should stay home as good wives and mothers (110).

Matsumura describes Okinawan resistance to government and corporate policies in both the textile and sugar industries. Female weavers continued making cloth independently, resisting efforts to establish wage-labor mass-production (111). Similarly, sugar producers refused to convert their family operations into suppliers of raw materials for factories.

Tainansha [company] and the prefecture continued to struggle to convert sugar manufacturers into cane cultivators. If additional family labor needed to be exhausted, farming families preferred to send a family 
member outside the village, prefecture, or country... [T] he peasants' reluctance to transform themselves into pure cultivators of cane can be understood as a significant act of anti-capitalist refusal that obstructed the transformation of their work and lives into dead labor, a process that would have remade them into alienated producers of raw materials or sellers of their labor power (144-145).

Economic conditions in what is still the nation's poorest prefecture compelled many Okinawans to emigrate to mainland Japan, to territories in the South Seas that were part of the Japanese colonial empire until 1945, and to Hawaii and the Americas. In cities on the mainland, where employment and housing discrimination against Okinawans was severe, migrants formed organizations such as the Kansai Okinawa Prefectural Association in Osaka, which is still home to the largest Okinawan diaspora in Japan. Its goals were "the mutual relief of members, the integration of members, the integration of the people of the prefecture and their progress" (159).

Its projects included providing refuge from natural disasters, treating illness, providing introductions to potential employers, providing help during periods of unemployment, maintaining communications with Okinawa, holding funerals and officiating at weddings. At the same time its leaders educated workers in Marxist-Leninist thought so as to equip them with knowledge of the importance of participating in strikes and fighting against their employers (159).

Leaders who returned to Okinawa in the early 1930s helped organize villagers in northern Okinawa fighting to alleviate tax burdens and transfer control of communal resources to local residents. Matsumura concludes: "The political victories that these participants were able to win, and the transformation of their demands and desires through the process of struggle, created enormous difficulties for state leaders who hoped that the northern periphery of Okinawa would remain nothing more than a source of cheap labor power that could be funneled into factories" (180).

Steve Rabson

Brown University

\section{Remi Kanazi, Before the Next Bomb Drops: Rising Up from Brooklyn to Palestine (Chicago: Haymarket Books, 2015). 100pp. Paperback \$16.00.}

Remi Kanazi's newest collection of poetry is a work of resistance born out of our immediate political moment. A poet, writer, and organizer based in New York City, Kanazi writes about the lives of Palestinians under occupation and as refugees around the world. He previously authored the collection Poetic Injustice: Writings on Resistance and Palestine (RoR Publishing, 2011) and edited the anthology Poets for Pales- 